\title{
Ferutinin Induces Membrane Depolarization, Permeability Transition Pore Formation, and Respiration Uncoupling in Isolated Rat Liver Mitochondria by Stimulation of $\mathrm{Ca}^{2+}$-Permeability
}

\author{
Tatsiana llyich ${ }^{3}$ - Oksana Charishnikova ${ }^{2}$. Szymon Sekowski ${ }^{1}$ Maria Zamaraeva ${ }^{1}$. Vitali Cheshchevik ${ }^{4}$. \\ Iosif Dremza ${ }^{5}$. Nina Cheshchevik ${ }^{4}$ - Lyudmila Kiryukhina ${ }^{3} \cdot$ Elena Lapshina $^{3} \cdot$ Ilya Zavodnik $^{3}$ (D)
}

Received: 8 November 2017 / Accepted: 24 March 2018 / Published online: 28 March 2018

(c) Springer Science+Business Media, LLC, part of Springer Nature 2018

\begin{abstract}
It is well known that the terpenoid ferutinin (4-oxy-6-(4-oxybenzoyloxy) dauc-8,9-en), isolated from the plant Ferula tenuisecta, considerably increases the permeability of artificial and cellular membranes to $\mathrm{Ca}^{2+}$-ions and produces apoptotic cell death in different cell lines in a mitochondria-dependent manner. The present study was designed for further evaluation of the mechanism(s) of mitochondrial effects of ferutinin using isolated rat liver mitochondria. Our findings provide evidence for ferutinin at concentrations of 5-27 $\mu \mathrm{M}$ to decrease state 3 respiration and the acceptor control ratio in the case of glutamate/ malate as substrates. Ferutinin alone $(10-60 \mu \mathrm{M})$ also dose-dependently dissipated membrane potential. In the presence of $\mathrm{Ca}^{2+}$-ions, ferutinin $(10-60 \mu \mathrm{M})$ induced considerable depolarization of the inner mitochondrial membrane, which was partially inhibited by EGTA, and permeability transition pore formation, which was diminished partly by cyclosporin A, and did not influence markedly the effect of $\mathrm{Ca}^{2+}$ on mitochondrial respiration. Ruthenium Red, a specific inhibitor of mitochondrial calcium uniporter, completely inhibited $\mathrm{Ca}^{2+}$-induced mitochondria swelling and membrane depolarization, but did not affect markedly the stimulation of these $\mathrm{Ca}^{2+}$-dependent processes by ferutinin. We concluded that the mitochondrial effects of ferutinin might be primarily induced by stimulation of mitochondrial membrane $\mathrm{Ca}^{2+}$-permeability, but other mechanisms, such as driving of univalent cations, might be involved.
\end{abstract}

Keywords Ferutinin $\cdot$ Mitochondria $\cdot \mathrm{Ca}^{2+}{ }_{\text {-ionophores }} \cdot$ Membrane potential $\cdot$ Respiration $\cdot$ Permeability transition pore

$\begin{array}{ll}\text { Abbreviations } \\ \text { ACR } & \text { Acceptor control ratio } \\ \text { CsA } & \text { Cyclosporin A } \\ \text { MCU } & \text { Mitochondrial calcium uniporter } \\ \text { MPT } & \text { Mitochondrial permeability transition }\end{array}$

Ilya Zavodnik

zavodnik_il@mail.ru

1 Department of Biophysics, University of Bialystok, Ciolkowskiego 1J, 15-245 Bialystok, Poland

2 National University of Uzbekistan named after Mirzo Ulugbek, Vuzgorodok, 700174 Tashkent, Uzbekistan

3 Department of Biochemistry, Yanka Kupala State University of Grodno, Blvd. Len. Kom. - 50, 230030 Grodno, Belarus

4 Department of Biotechnology, Polessky State University, Dnieprovskoy Flotilii, 23, 225710 Pinsk, Brest Region, Belarus

5 Department of Pathophysiology, State Medical University of Grodno, Gorkogo, 80, 230015 Grodno, Belarus
ROS Reactive oxygen species

$\mathrm{Ru}$ red Ruthenium red

FCCP Carbonyl cyanide p-trifluoro-methoxyphenyl hydrazine

\section{Introduction}

There is a strong interest to plant compounds as potential pharmacological agents due to their effectivity, safety and a wide spectrum of biological activities, including anticancer effect (Amin et al. 2009; Fulda 2010; Mondal et al. 2012; Ouyang et al. 2014). Terpenoids are quite promising as chemotherapeutic agents among potential anticancer drugs (Modzelewska et al. 2005; Dall' Acqua et al. 2011; Safi et al. 2016; Suta et al. 2017). One of such compounds is ferutinin, a sesquiterpene isolated from plants of Ferula genus (Umbelliferae family). Ferutinin (4-oxy-6-(4-oxybenzoyloxy) dauc-8,9-en), ester of sesquiterpenic alcohol with aromatic p-hydroxybenzoic acid (Saidkhodzjaev and 
Nikonov 1973), possesses high estrogenic activity and acts as an agonist to estrogen receptor ER $\alpha$ and agonist/antagonist to estrogen ER $\beta$-receptor (Safi et al. 2016; Ignatkov et al. 1990; Zamaraeva et al. 1999; Ikeda et al. 2002; Ferretti et al. 2014). Numerous studies reported marked toxicity of ferutinin to cancer cells compared to non-tumoural cells. In experiments in vivo, the antitumor activity of ferutinin was similar to the activity of cisplatin (Matin et al. 2014; Arghiani et al. 2014). Ferutinin manifested antiproliferative activity, inducing apoptosis in several cell types: MCF-7 estrogen-dependent cancer cells, leukemia T-cell line (Jurkat), human and mouse colon carcinoma cells (Caco-2, CT26, HT29), as well as bladder (TCC) cancer cells (Arghiani et al. 2014; Lhuillier et al. 2005; Macho et al. 2004). This terpenoid also showed a marked inhibitory effect against colon cancer cells (COLO 320HSR), blocking cell transition from G0/G1 into $S$ phase of the cell cycle. The antiproliferative activity of ferutinin was assumed to be associated with interaction with estrogen type II binding sites (Poli et al. 2005). Moreover, ferutinin exhibited antibacterial and antiinflammatory activities (Geroushi et al. 2011), potentiated bone mineralization (Zavatti et al. 2015), and was proposed to be used as an antiosteoporosis phytoestrogen (Ferretti et al. 2012).

On the other hand, ferutinin acts as an electrogenic $\mathrm{Ca}^{2+}$-ionophore that has been shown to use planar lipid bilayers membranes and liposomes (Zamaraeva et al. 1997; Abramov et al. 2001; Dubis et al. 2015). Similarly, earlier works showed that ferutinin at concentrations of $1-50 \mu \mathrm{M}$ considerably increased $\mathrm{Ca}^{2+}$-permeability of thymocytes, platelets, Jurkat T-cell, erythrocytes, mitochondria, and sarcoplasmic reticulum (Zamaraeva et al. 1997, 1999, 2010; Macho et al. 2004; Gao et al. 2013). Ferutinin interacts strongly with $\mathrm{Ca}^{2+}$-ions via the hydroxyl group of ferutinol and the carboxyl oxygen of the complex ether bond (Dubis et al. 2015). It was demonstrated previously using FT-IR and NMR data together with theoretical calculations that in the absence of $\mathrm{Ca}^{2+}$ ions ferutinin molecules formed $\mathrm{H}$-bonded dimers while complexation of $\mathrm{Ca}^{2+}$ by ferutinin ruptured this hydrogen bond due to spatial re-orientation of the ferutinin molecules from parallel to antiparallel alignment (Zamaraeva et al. 1997; Abramov et al. 2001; Dubis et al. 2015). According to the conductometry data, the stoichiometry of the complex of ferutinin with calcium ion in acetone was $2: 1$. In contrast, the stoichiometry of ferutinin- $\mathrm{Ca}^{2+}$ complexes in the membrane was $1: 1$. It was demonstrated using Jurkat T-cells and erythrocytes, but not platelets, that an increase in cytosolic $\mathrm{Ca}^{2+}$ at lower doses of ferutinin was connected with activation of $P$ - and $L$-types of membranous $\mathrm{Ca}^{2+}$ channels (Macho et al. 2004; Zamaraeva et al. 2010; Gao et al. 2013). The study of $\mathrm{Ca}^{2+}$-ionophoric effects of ferutinin on neurons and hepatocytes demonstrated that increase in cytosolic $\mathrm{Ca}^{2+}$ was accompanied by accumulation of $\mathrm{Ca}^{2+}$ in mitochondria and, as a result, this was followed by depolarization of mitochondrial membranes, which could be prevented by cyclosporine A (CsA), an inhibitor of mitochondrial permeability transition (MPT) pore formation (Abramov and Duchen 2003). Moreover, ferutinin-induced apoptosis in Jurkat cells with preceded CsA sensitive loss of mitochondrial transmembrane potential and an increase in intracellular reactive oxygen species (ROS). Ferutinin-induced DNA fragmentation was mediated by the caspase-3-dependent pathway but was not prevented by CsA completely (Macho et al. 2004). Moreover, it was shown that other sesquiterpene, teferin, also induced apoptosis in Jurkat cell, increasing cytosolic $\mathrm{Ca}^{2+}$ level (Macho et al. 2004). Ferutinin caused in vitro eryptosis/erythroptosis in human erythrocytes by means of membrane permeabilization and simultaneous enhancement of caspase- 3 activity and $\mathrm{Ca}^{2+}$ influx (Gao et al. 2013). However, calcium does not seem to be the sole mediator in the ferutinin-mediated eryptosis/ erythroptosis (Gao et al. 2013).

The above-mentioned indicates interrelation of the antiproliferative and $\mathrm{Ca}^{2+}$-transporting activities of ferutinin, which results in apoptosis via mitochondrial pathway action and MPT pore formation. Mitochondria serve as the main target for anticancer drugs (Gorlach et al. 2015), and MPT pore formation is the key mechanism of these drugs action (Costantini et al. 2000; Dalla Via et al. 2014).

Alterations in mitochondrial function have long been associated with numerous metabolic disorders (Duchen 2004). Mitochondrial $\mathrm{Ca}^{2+}$ signaling plays an important role in cell life and death (Kowaltowski 2000; Szewczyk and Wojtczak 2002). When accumulated by mitochondria at high levels and associated with conditions of oxidative stress, $\mathrm{Ca}^{2+}$ ions can lead to extensive changes in mitochondrial functions, including a non-selective form of inner membrane permeabilization known as MPT, which causes cell death either by energetic collapse or by initiating mitochondrial swelling, cytochrome $c$ release, and apoptotic cascade (Azzolin et al. 2010). The fundamental transport mechanism for $\mathrm{Ca}^{2+}$ accumulation in mitochondria was shown to be associated with a low-affinity electrogenic Ruthenium red (Ru red) and lanthanides-sensitive mitochondrial calcium uniporter, MCU (or transmembrane protein CCDC109A), which was likely to be a channel (Kirichok et al. 2004; Baughman et al. 2011; De Stefani et al. 2011). The concept of MCU oligomerization opens the possibility that, together with $\mathrm{MCU}$, other related proteins MCUb and EMRE, as well as the regulatory proteins MICU1 (mitochondrial $\mathrm{Ca}^{2+}$ uptake 1), MCUR1 (mitochondrial $\mathrm{Ca}^{2+}$ uniporter regulator 1), and MICU2, MICU3, MCUR1, and SLC25A23 could be components of the channel complex which regulates the influx of $\mathrm{Ca}^{2+}$ across the inner mitochondrial membrane and maintain many mitochondrial metabolic functions (Hoffman et al. 2014). An increase in mitochondrial $\mathrm{Ca}^{2+}$ activates three dehydrogenases in the mitochondrial matrix: pyruvate 
dehydrogenase, oxoglutarate dehydrogenase, and isocitrate dehydrogenase.

Search for drugs that regulate $\mathrm{Ca}^{2+}$ homeostasis in cells and mitochondria is the task of great interest. $\mathrm{Ca}^{2+}$-ionophores have often been applied to cells in order to induce $\mathrm{Ca}^{2+}$-dependent processes in mitochondria (Abramov et al. 2001; Abramov and Duchen 2003). Experiments on the ferutinin effect on mitochondrial functional parameters were carried out previously on the whole cells, assuming direct as well as indirect (modulating of cellular signaling cascades due to receptor activation) modes of action. Therefore, it was of interest to study the mechanism(s) of the ferutinin effect on isolated mitochondria and estimate a possible role of mitochondrial functional changes in anticancer activity of ferutinin. It was suggested that ferutinin, due to high cytotoxic and apoptosis-inducing activities in different lines of cancer cells, could be considered as an effective anticancer agent for future experiments, both in vivo and in the clinical studies (Matin et al. 2014). The aim of the present work was to evaluate the effects of ferutinin on mitochondrial respiration, MPT pore formation, and membrane potential both in the absence and the presence of calcium ions using isolated rat liver mitochondria.

\section{Materials and Methods}

\section{Chemicals}

Calcium chloride, succinate, glutamate, malate, safranin $\mathrm{O}$, carbonyl cyanide p-trifluoro-methoxyphenyl hydrazone (FCCP), cyclosporin A (CsA), dimethyl sulfoxide (DMSO), and ADP were purchased from Sigma-Aldrich Chemie $\mathrm{GmbH}$ (Steinheim, Germany). Ruthenium red (Ru red) was purchased from Calbiochem/Sigma-Aldrich Chemie GmbH (Steinheim, Germany). All other reagents were purchased from POCh (Gliwice, Poland) and Reakhim (Moscow, Russia) and were of analytical grade. Ferutinin was kindly provided as a gift by Dr. Saidkhodzjaev (Institute of Chemistry of Plant Substances, Uzbekistan). Ferutinin was isolated from the roots of Ferula tenuisecta by the method of Saidkhodjaev and Nikonov (Saidkhodjaev and Nikonov 1973). According to the GC-MS analysis, the purity of ferutinin was $96 \pm 2 \%$ (Zamaraeva et al. 2010). We used ferutinin as $1 \mathrm{mM}$ stock solution in DMSO. CsA was dissolved in 50\% ethanol. All the solutions were made with water purified in the Milli-Q system.

\section{Rat Liver Mitochondria: Isolation and Respiration Measurements}

All manipulations with animals were performed according to the European Convention for the Protection of Vertebrate Animals used for Experimental and Other Scientific Purposes.
Mitochondria were isolated from the rat liver by the standard procedure of differential centrifugation (Johnson and Lardy 1967). The isolation medium contained $0.25 \mathrm{M}$ sucrose, $0.01 \mathrm{M}$ Tris- $\mathrm{HCl}, 0.001 \mathrm{M} \mathrm{KH}_{2} \mathrm{PO}_{4}$, and $0.001 \mathrm{M}$ EGTA, pH 7.2. The mitochondrial pellet was resuspended in the buffer to an approximate protein concentration of $35-40 \mathrm{mg} / \mathrm{ml}$. The protein concentration was determined according to Lowry et al. (1951).

The respiration (oxygen consumption rate) of mitochondria (1 $\mathrm{mg}$ of protein/ml) was measured using a laboratorymade oxygen Clark-type electrode and a hermetic polarographic cell (volume $1.25 \mathrm{ml}$ ) at constant gentle stirring (Dremza et al. 2006). The incubation medium contained $0.125 \mathrm{M} \mathrm{KCl}, 0.05 \mathrm{M}$ sucrose, $0.01 \mathrm{M}$ Tris-HCl, $0.0025 \mathrm{M}$ $\mathrm{KH}_{2} \mathrm{PO}_{4}, 0.005 \mathrm{M} \mathrm{MgSO}_{4}$ with $0.001 \mathrm{M}$ EGTA (EGTAcontaining) or without EGTA (EGTA-free medium), $\mathrm{pH}$ 7.4. The experiments were performed at $25^{\circ} \mathrm{C}$ using $5 \mathrm{mM}$ glutamate and $1 \mathrm{mM}$ malate as respiratory substrates. The mitochondria were preincubated with $\mathrm{Ca}^{2+}$ or ferutinin for $2 \mathrm{~min}$ and the respiratory substrates were injected into the cell. The functional state of mitochondria was determined by the acceptor control ratio (ACR), equal to the ratio of the respiratory rates $\left(V_{3} / V_{2}\right)$ of mitochondria in States 3 and 2. The coefficient of phosphorylation (ADP/O) was calculated as the ratio of the amount of ADP added to the amount of oxygen consumed throughout phosphorylation. State $2\left(V_{2}\right)$ corresponded to the mitochondria respiration in the presence of substrates (glutamate/malate). State $3\left(V_{3}\right)$ respiration was recorded after addition of $180 \mu \mathrm{M}$ ADP into the medium.

\section{Mitochondrial Swelling}

$\mathrm{Ca}^{2+}$-induced mitochondrial swelling was analyzed as changes in intensity of light scattering by mitochondrial suspension, which was determined by measuring absorbance of the suspension at $520 \mathrm{~nm}\left(D^{520} / D_{0}{ }^{520}\right.$, where $D_{0}{ }^{520}$ is the initial absorbance of the suspension at time 0 ) and $25^{\circ} \mathrm{C}$. The incubation medium for energized mitochondria contained $0.125 \mathrm{M} \mathrm{KCl}, 0.01 \mathrm{M}$ Tris- $\mathrm{HCl}, 0.0025 \mathrm{M} \mathrm{KH}_{2} \mathrm{PO}_{4}$, $0.001 \mathrm{M}$ EGTA, $\mathrm{pH} 7.4$, as well as $5 \mathrm{mM}$ L-glutamate and $1 \mathrm{mM}$ L-malate as substrates, whereas that for de-energized mitochondria was $0.24 \mathrm{M}$ sucrose, $0.01 \mathrm{M}$ Tris- $\mathrm{HCl}$, $0.001 \mathrm{M}$ EGTA, and $1 \mu \mathrm{M}$ rotenone (Petronilli et al. 1993a, b). Isolated mitochondria $(0.5 \mathrm{mg}$ of protein $/ \mathrm{ml})$ were added to the media containing respiratory substrates. Mitochondria were incubated with ferutinin and/or CsA (or Ru red) for 5 min prior to the introduction of $\mathrm{Ca}^{2+}$ ions, and the rate of the decrease $\left(\Delta D^{520} / \mathrm{min}\right)$ in light scattering intensity was used to determine the extent of mitochondrial pore opening. The rate of the termination phase of swelling was measured (Baranov et al. 2008). At the end of the measurements, the uncoupler FCCP $(0.5 \mu \mathrm{M})$ was added to mitochondria to control the finishing of the process of MPT. 


\section{Mitochondrial Membrane Potential Measurements}

Mitochondrial membrane potential was detected with a Perkin-Elmer LS55 spectrofluorimeter (Great Britain) with the use of the fluorescent dye safranin $\mathrm{O}(8 \mu \mathrm{M})$ at $\lambda_{\mathrm{ex}} / \lambda_{\mathrm{em}}$ $495 / 586 \mathrm{~nm}$ (Akerman and Wikström 1976; Moore and Bonner 1982) in the buffer containing $0.05 \mathrm{M}$ sucrose, $0.125 \mathrm{M}$ $\mathrm{KCl}, 0.01 \mathrm{M}$ Tris- $\mathrm{HCl}, 0.0025 \mathrm{M} \mathrm{KH}_{2} \mathrm{PO}_{4}, 0.005 \mathrm{M} \mathrm{MgSO}_{4}$, and $1 \mathrm{mM}$ EGTA or without EGTA (EGTA-free medium), $\mathrm{pH} 7.4,25^{\circ} \mathrm{C}$, using $5 \mathrm{mM}$ glutamate and $1 \mathrm{mM}$ malate as substrates, at constant gentle stirring. The positively charged dye was accumulated by mitochondria $(0.3 \mathrm{mg}$ protein $/ \mathrm{ml})$ depending on their potential, with the intramitochondrial dye accumulation resulting in fluorescence quenching. The mitochondrial membrane potential values $(\mathrm{mV})$ were determined applying a calibration plot which represented the dependence of safranine $\mathrm{O}$ fluorescence intensity on the mitochondrial membrane potential value, calculated according to the Nernst equation:

$\Delta \Psi=60 \log \left[\mathrm{K}^{+}\right]_{\text {out }} /\left[\mathrm{K}^{+}\right]_{\text {in }}(\mathrm{mV})$,

where the $\left[\mathrm{K}^{+}\right]_{\text {in }}$ is the intramitochondrial potassium concentration $(120 \mathrm{mM})$ and the $\left[\mathrm{K}^{+}\right]_{\text {out }}$ is the extramitochondrial potassium concentration in the medium that varies from 0 to $20 \mathrm{mM}$ (Akerman and Wikström 1976; Moore and Bonner 1982). Complete depolarization of mitochondria to calibrate the dye fluorescence was achieved by addition of FCCP $(0.5 \mu \mathrm{M})$.

\section{Statistical Analysis}

The data for 5-6 experiments are presented as a mean \pm SD for the normally distributed parameters. We used the standard Student's $t$ test for the comparison of the data showing no departures from normality according to Shapiro-Wilk's test. $P<0.05$ was taken to indicate statistical significance. The calculations were performed using the GraphPad software.

\section{Results}

\section{Ferutinin Enhanced $\mathrm{Ca}^{2+}$-Induced Rat Liver Mitochondrial Permeability Transitions}

Figure 1 shows representative traces of de-energized mitochondrial (in the absence of substrates and the presence of $1 \mu \mathrm{M}$ rotenone) swelling, induced by $\mathrm{Ca}^{2+}$ in the absence and in the presence of ferutinin (mitochondrial pore formation was registered in the presence of $1 \mathrm{mM}$ EGTA). Ferutinin $\left(16.6 \mu \mathrm{M}\right.$, in the absence of $\mathrm{Ca}^{2+}$-ions) did not induce any mitochondrial swelling (Fig. 1). In accordance with numerous observations, the exposure of mitochondria to exogenous $\mathrm{Ca}^{2+}$-ions resulted in effective MPT pore formations. Ferutinin $(8.3-16.6 \mu \mathrm{M})$ dose-dependently increased the rate of $\mathrm{Ca}^{2+}$-induced swelling of de-energized mitochondria (Fig. 1). Similar results were obtained for respiring mitochondria energized by $5 \mathrm{mM}$ glutamate $/ 1 \mathrm{mM}$ malate (Fig. 2). Ferutinin at a concentration of $16.6 \mu \mathrm{M}$ increased the rate of pore formation by $140 \%$ for de-energized mitochondria and by $180 \%$ for mitochondria oxidizing substrates. As electrogenic $\mathrm{Ca}^{2+}$-ionophore, ferutinin enhanced the effectiveness of ion transportation into mitochondria and the MPT pore formations.

We measured the effect of the known MPT pore blocker, $\mathrm{CsA}$, on $\mathrm{Ca}^{2+}$-ferutinin-dependent pore formation. In our experiments, CsA $(0.2 \mu \mathrm{M})$ completely inhibited $\mathrm{Ca}^{2+}$-induced mitochondria swelling (Fig. 3) and partially

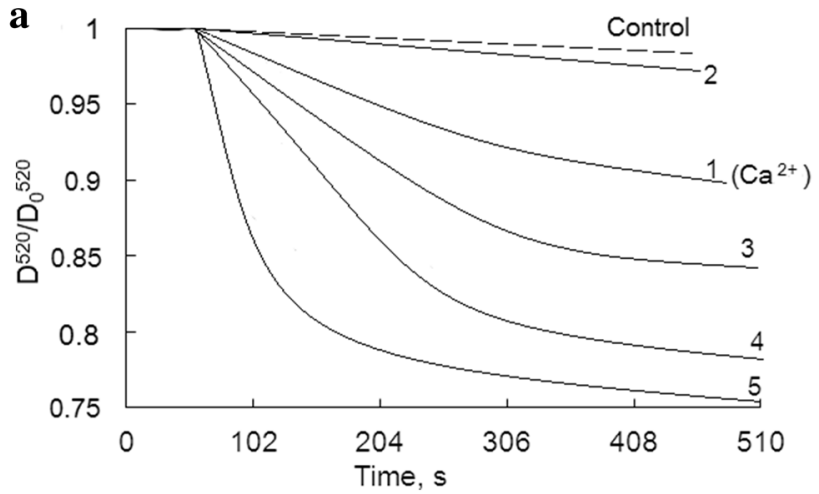

b

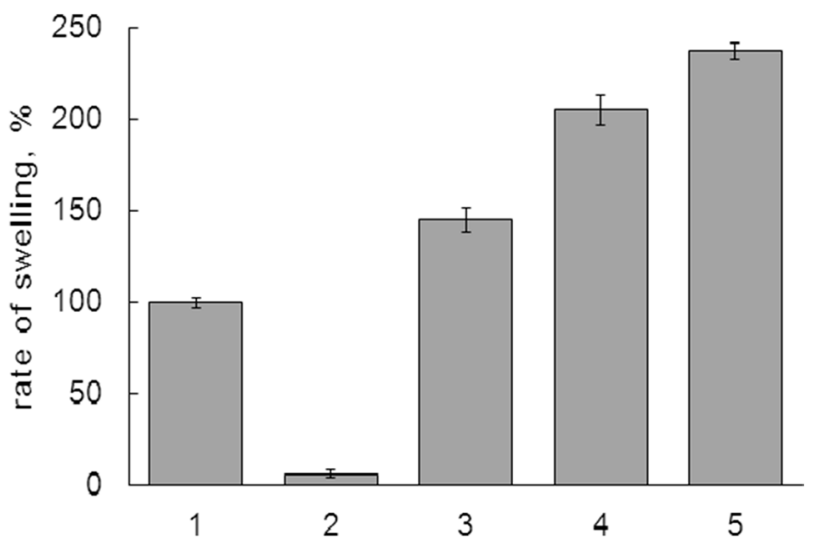

Fig. 1 Effect of ferutinin on $\mathrm{Ca}^{2+}$-induced MPT pore formation in de-energized rat liver mitochondria. a Representative swelling traces; b $\mathrm{Ca}^{2+}$ induced mitochondrial swelling rate at varying ferutinin concentrations. Designations: control, mitochondria in the absence of $\mathrm{Ca}^{2+}$-ions; $1200 \mu \mathrm{M} \mathrm{Ca}^{2+}$; $216.6 \mu \mathrm{M}$ ferutinin; 3 $200 \mu \mathrm{M} \mathrm{Ca}{ }^{2+}+8.3 \mu \mathrm{M}$ ferutinin; $4200 \mu \mathrm{M} \mathrm{Ca}^{2+}+12.5 \mu \mathrm{M}$ ferutinin; $5200 \mu \mathrm{M} \mathrm{Ca}^{2+}+16.6 \mu \mathrm{M}$ ferutinin. The mitochondrial swelling rate $\left(\Delta D^{520} / \mathrm{min}\right.$ ) in the presence of $\mathrm{Ca}^{2+}$ was assumed to be $100 \%$. Mitochondria $(0.5 \mathrm{mg}$ of protein $/ \mathrm{ml})$ were added into EGTA-containing medium: 0.24 M sucrose, 0.01 M Tris-HCl, 0.001 M EGTA, pH 7.4, $1 \mu \mathrm{M}$ rotenone, at $25^{\circ} \mathrm{C}$ 
decreased the rate of $\mathrm{Ca}^{2+}$-induced mPTP formation in the presence of ferutinin. Our findings demonstrated that the effect of ferutinin on $\mathrm{Ca}^{2+}$-dependent MPT was mainly due to increased inner mitochondrial membrane permeability to $\mathrm{Ca}^{2+}$-ions. At the same time, a part of $\mathrm{Ca}^{2+}$-induced MPT pores in the presence of ferutinin was not blocked by CsA.

At higher concentrations $(20-60 \mu \mathrm{M})$, ferutinin dosedependently produced mitochondrial swelling in EGTA-free medium, probably due to the presence of endogenous $\mathrm{Ca}^{2+}$ ions (Fig. 4a). Ru red (1 $\mu \mathrm{M})$, preventing mitochondrial $\mathrm{Ca}^{2+}$ influx due to MCU inhibition, completely excluded $\mathrm{Ca}^{2+}$-induced MPT pore formation in both the EGTA-free (Fig. 4a, curve 2) and EGTA-containing (Fig. 4b, curve 3) media. In the presence of Ru red, ferutinin $(5-60 \mu \mathrm{M})$ restored the ability of $\mathrm{Ca}^{2+}$ to induce mitochondria swelling and considerably enhanced the rate of $\mathrm{Ca}^{2+}$-mediated MPT

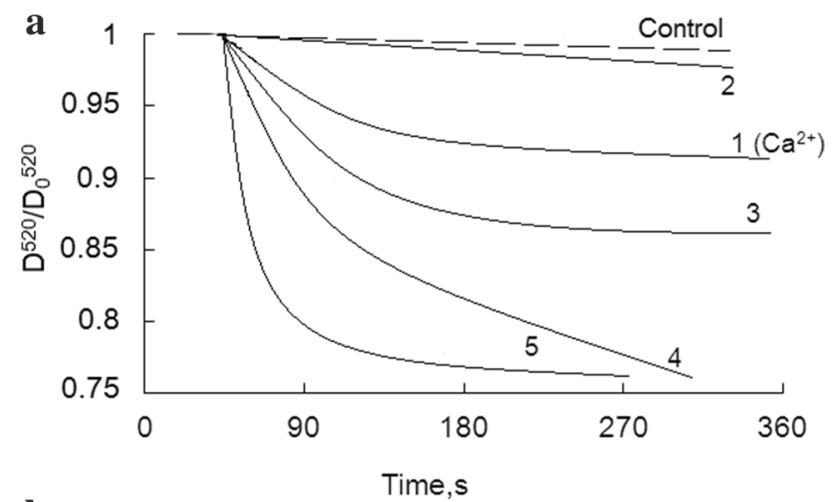

b

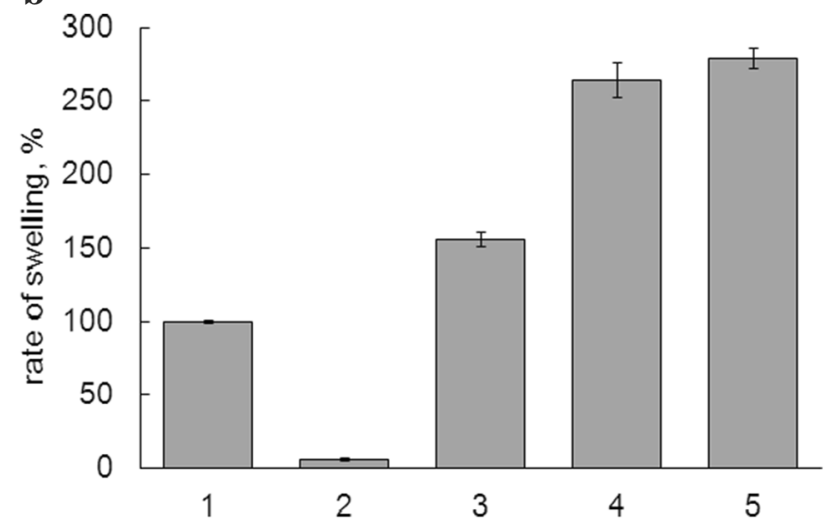

Fig. 2 Effect of ferutinin on $\mathrm{Ca}^{2+}$-induced MPT pore formation in respiring rat liver mitochondria. a Representative swelling traces of mitochondria, energized by malate/glutamate; $\mathbf{b} \mathrm{Ca}^{2+}$ induced mitochondrial swelling rate at varying ferutinin concentrations. Designations: control, mitochondria in the absence of $\mathrm{Ca}^{2+}$-ions; $1200 \mu \mathrm{M}$ $\mathrm{Ca}^{2+} ; 216.6 \mu \mathrm{M}$ ferutinin; $3200 \mu \mathrm{M} \mathrm{Ca}{ }^{2+}+8.3 \mu \mathrm{M}$ ferutinin; 4 $200 \mu \mathrm{M} \mathrm{Ca}{ }^{2+}+12.5 \mu \mathrm{M}$ ferutinin; $5200 \mu \mathrm{M} \mathrm{Ca}^{2+}+16.6 \mu \mathrm{M}$ ferutinin. The mitochondrial swelling rate $\left(\Delta D^{520} / \mathrm{min}\right)$ in the presence of $\mathrm{Ca}^{2+}$ was assumed to be $100 \%$. Mitochondria (0.5 mg of protein/ $\mathrm{ml})$ were introduced into EGTA-containing medium: $0.125 \mathrm{M} \mathrm{KCl}$, $0.01 \mathrm{M}$ Tris- $\mathrm{HCl}, 0.0025 \mathrm{M} \mathrm{KH}_{2} \mathrm{PO}_{4}, 0.005 \mathrm{M} \mathrm{MgSO}_{4}, \mathrm{pH} 7.4$, $0.001 \mathrm{M}$ EGTA, $5 \mathrm{mM}$ glutamate, and $1 \mathrm{mM}$ malate, at $25^{\circ} \mathrm{C}$
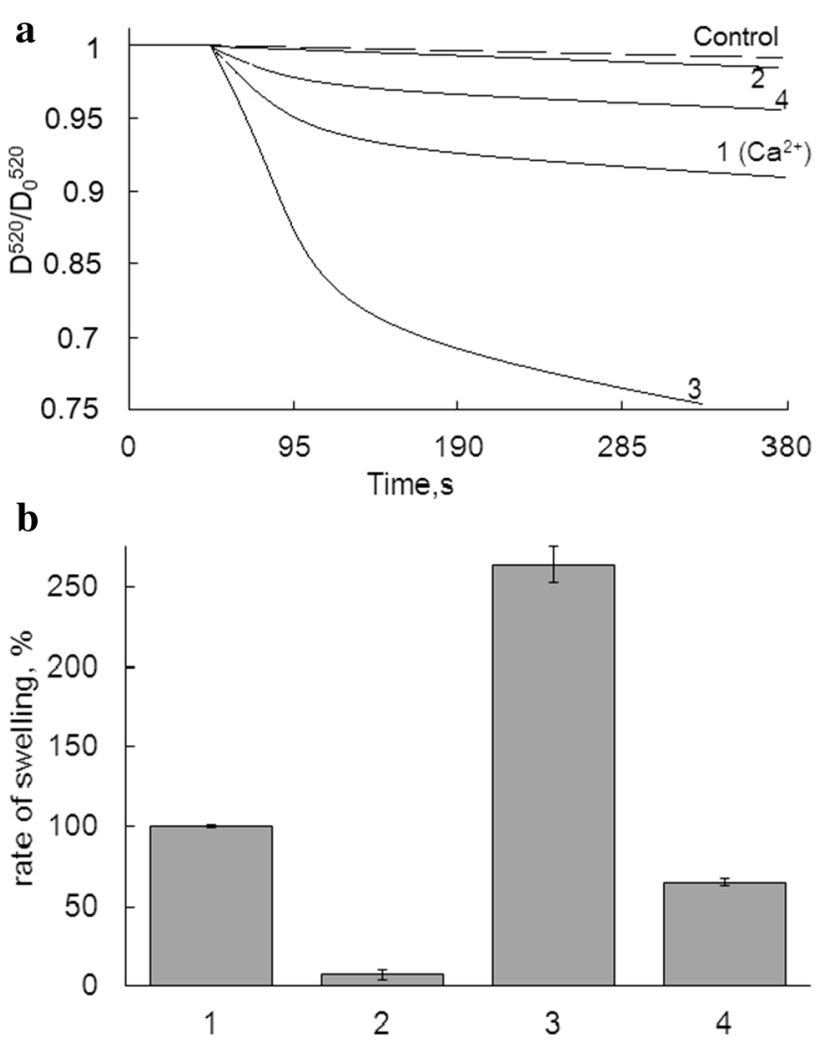

Fig. 3 Inhibition of $\mathrm{Ca}^{2+}$-induced swelling of respiring rat liver mitochondria by CsA and effect of ferutinin. a Representative swelling traces of mitochondria, energized by malate/glutamate; $\mathbf{b}$ effect of ferutinin and CsA on swelling of energized mitochondria. Designations: control, mitochondria in the absence of $\mathrm{Ca}^{2+}{ }_{\text {-ions; }} 1200 \mu \mathrm{M}$ $\mathrm{Ca}^{2+} ; 2200 \mu \mathrm{M} \mathrm{Ca}^{2+}+0.2 \mu \mathrm{M} \mathrm{CsA} ; 3200 \mu \mathrm{M} \mathrm{Ca}^{2+}+12.5 \mu \mathrm{M}$ ferutinin; $4200 \mu \mathrm{M} \mathrm{Ca}^{2+}+12.5 \mu \mathrm{M}$ ferutinin $+0.2 \mu \mathrm{M}$ CsA. The rate of mitochondria swelling $\left(\Delta D^{52 \%} / \mathrm{min}\right)$ in the presence of $\mathrm{Ca}^{2+}$ was assumed to be $100 \%$. Mitochondria $(0.5 \mathrm{mg}$ of protein $/ \mathrm{ml})$ were introduced into EGTA-containing medium: $0.125 \mathrm{M} \mathrm{KCl}, 0.01 \mathrm{M}$ Tris$\mathrm{HCl}, 0.0025 \mathrm{M} \mathrm{KH}_{2} \mathrm{PO}_{4}, 0.005 \mathrm{M} \mathrm{MgSO}_{4}, 0.001 \mathrm{M}$ EGTA, pH 7.4, $5 \mathrm{mM}$ glutamate, and $1 \mathrm{mM}$ malate, at $25^{\circ} \mathrm{C}$

(Fig. 4) (Similar results were obtained for mitochondria energized by both $5 \mathrm{mM}$ glutamate/ $1 \mathrm{mM}$ malate and $5 \mathrm{mM}$ succinate, data not shown.).

\section{Ferutinin Influenced Rat Liver Mitochondria Respiration}

Using isolated rat liver mitochondria, we measured the effect of $\mathrm{Ca}^{2+}$ and ferutinin on mitochondrial respiration parameters. In the absence and in the presence of ferutinin, $\mathrm{Ca}^{2+}$ dose-dependently decreased State 3 respiration rate and ACR, leaving State 2 respiration and phosphorylation coefficient ADP/O unchanged (Figs. 5, 6). Ferutinin at a concentration of $27 \mu \mathrm{M}$ slightly enhanced the effects of calcium on mitochondrial respiration.

In our experiments, ferutinin alone (at concentrations of 5-27 $\mu \mathrm{M}$ ) increased the substrate (glutamate/ 

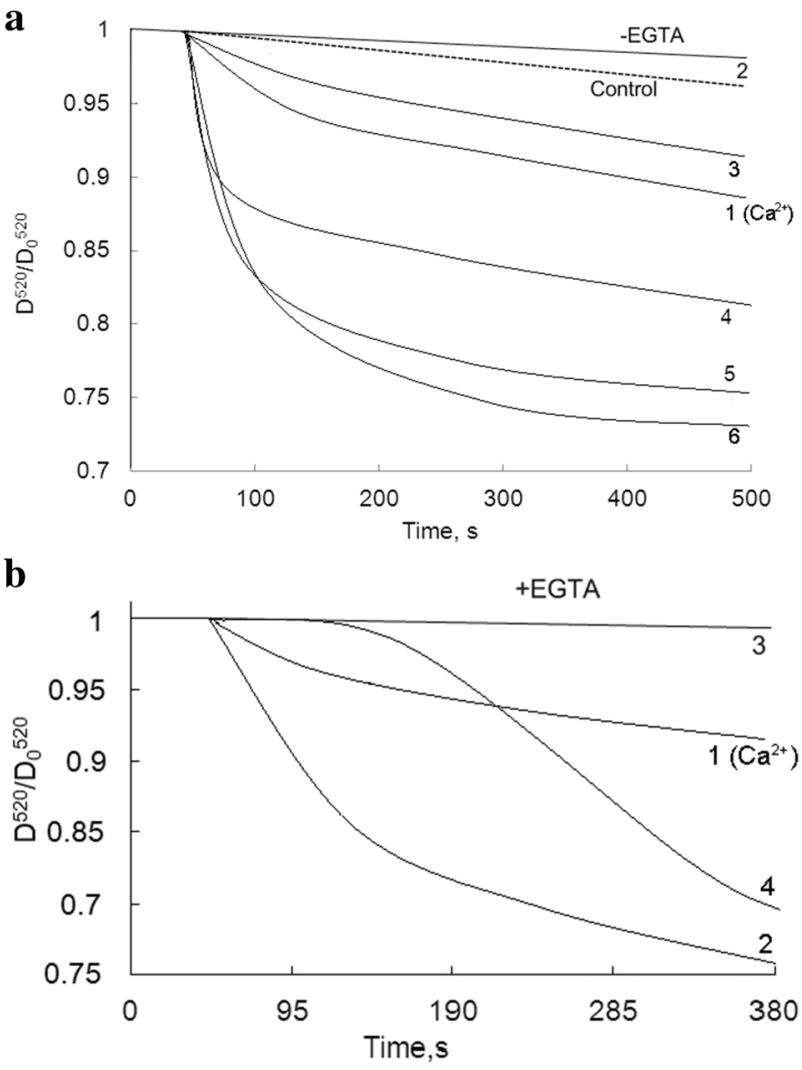

Fig. 4 Inhibition of $\mathrm{Ca}^{2+}$-induced swelling of energized rat liver mitochondria by Ruthenium red and effect of ferutinin. a Representative swelling traces of mitochondria energized by malate/glutamate in EGTA-free medium. Designations: control, mitochondria in the absence of $\mathrm{Ca}^{2+}$-ions; $160 \mu \mathrm{M} \mathrm{Ca}^{2+} ; 21 \mu \mathrm{M} \mathrm{Ru}$ red $+60 \mu \mathrm{M}$ $\mathrm{Ca}^{2+}$; $320 \mu \mathrm{M}$ ferutinin; $460 \mu \mathrm{M}$ ferutinin; $51 \mu \mathrm{M} \mathrm{Ru}$ red $+60 \mu \mathrm{M}$ $\mathrm{Ca}^{2+}+20 \mu \mathrm{M}$ ferutinin; $61 \mu \mathrm{M} \mathrm{Ru}$ red $+60 \mu \mathrm{M} \mathrm{Ca}^{2+}+60 \mu \mathrm{M}$ ferutinin. b Effect of Ru red $(1 \mu \mathrm{M})$ on $\mathrm{Ca}^{2+}(200 \mu \mathrm{M})$-induced mitochondria swelling in the presence of ferutinin $(12.5 \mu \mathrm{M})$ : representative swelling traces of mitochondria energized by malate/glutamate in EGTA-containing medium. Designations: $1200 \mu \mathrm{M} \mathrm{Ca}^{2+} ; 2200 \mu \mathrm{M}$ $\mathrm{Ca}^{2+}+12.5 \mu \mathrm{M}$ ferutinin; $31 \mu \mathrm{M} \mathrm{Ru}$ red $+200 \mu \mathrm{M} \mathrm{Ca}^{2+} ; 41 \mu \mathrm{M}$ $\mathrm{Ru}$ red $+200 \mu \mathrm{M} \mathrm{Ca}^{2+}+12.5 \mu \mathrm{M}$ ferutinin. Mitochondria $(0.5 \mathrm{mg}$ of protein/ml) were introduced into EGTA-free or EGTA-containing media: $0.125 \mathrm{M} \mathrm{KCl}, 0.01 \mathrm{M}$ Tris- $\mathrm{HCl}, 0.0025 \mathrm{M} \mathrm{KH}_{2} \mathrm{PO}_{4}, 0.005 \mathrm{M}$ $\mathrm{MgSO}_{4}, \mathrm{pH} 7.4,0.001 \mathrm{M}$ EGTA (or without EGTA), $5 \mathrm{mM}$ glutamate, and $1 \mathrm{mM}$ malate, at $25^{\circ} \mathrm{C}$

malate)-dependent State 2 respiration and decreased State 3 respiration of isolated rat liver mitochondria, which resulted in diminishing the acceptor control ratio State 3/State 2 and the phosphorylation coefficient ADP/O. In the presence of $20 \mu \mathrm{M} \mathrm{Ca}^{2+}$-ions in the medium, the effects of ferutinin on mitochondrial respiration increased (Fig. 6).

We can conclude that ferutinin influenced mitochondrial respiration as $\mathrm{Ca}^{2+}$-ionophore, resulting in inhibition of ADP-stimulated oxygen consumption and uncoupling of the respiration. At the same time, ferutinin had an effect on the mitochondrial respiration, not only as $\mathrm{Ca}^{2+}$-ionophore. One can assume a protonophoric effect of ferutinin.
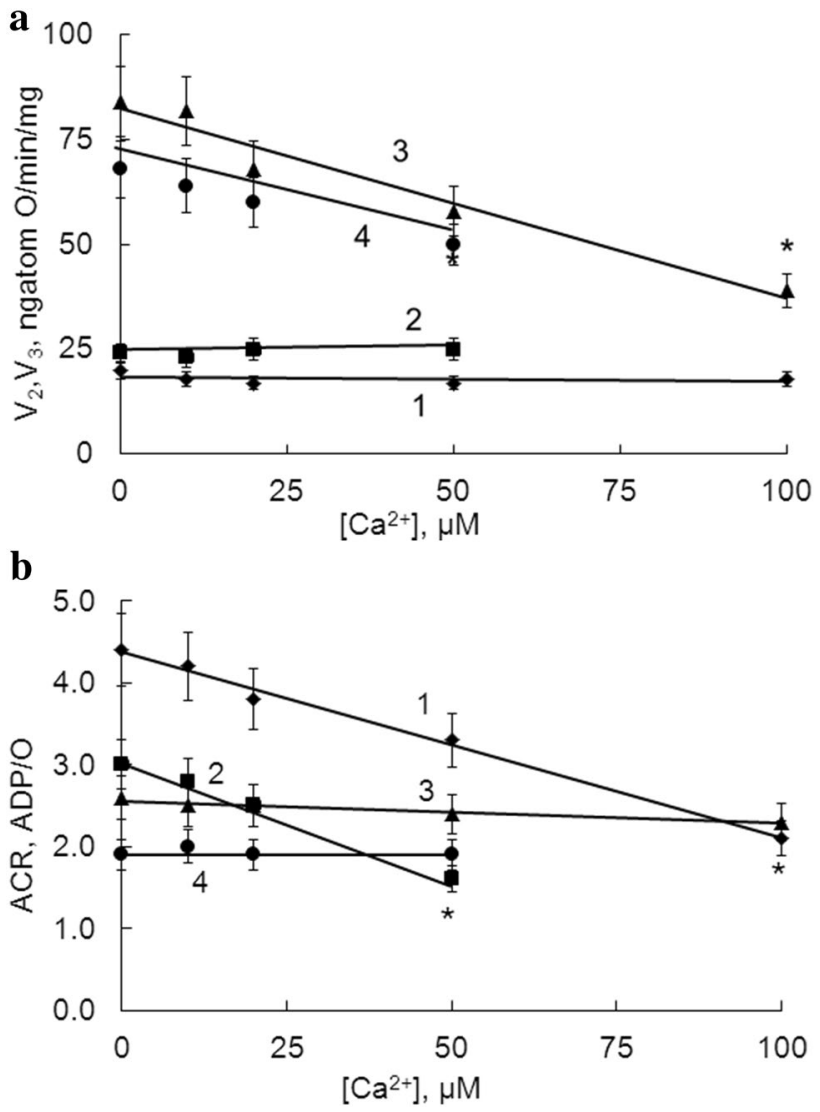

Fig. 5 Effect of $\mathrm{Ca}^{2+}$ on respiration parameters of rat liver mitochondria in the absence $(1,3)$ and in the presence of $27 \mu \mathrm{M}$ ferutinin $(2$, 4). a Substrate-dependent oxygen consumption rate, State $2(1,2)$ and ADP-stimulated oxygen consumption rate, State $3(3,4)$; b acceptor control ratio $\operatorname{ACR}(1,2)$ and phosphorylation coefficient ADP/O (3, 4). Mitochondria $(0.5 \mathrm{mg}$ of protein $/ \mathrm{ml})$ were introduced into EGTAfree medium: $0.125 \mathrm{M} \mathrm{KCl}, 0.05 \mathrm{M}$ sucrose, $0.01 \mathrm{M}$ Tris- $\mathrm{HCl}$, $0.0025 \mathrm{M} \mathrm{KH}_{2} \mathrm{PO}_{4}, 0.005 \mathrm{M} \mathrm{MgSO}_{4}, \mathrm{pH} 7.4,5 \mathrm{mM}$ glutamate, and $1 \mathrm{mM}$ malate, at $25^{\circ} \mathrm{C}$

\section{Ferutinin Promoted $\mathrm{Ca}^{2+}$-Induced Mitochondrial Depolarization}

Figures 7 and $8 \mathrm{a}$, b show changes in the mitochondrial membrane potential induced by $\mathrm{Ca}^{2+}$ and ferutinin and measured by fluorescence of the potential-sensitive probe safranine $\mathrm{O}$. In the EGTA-free medium, $\mathrm{Ca}^{2+}$ at concentrations of 10-60 $\mu \mathrm{M}$ dose-dependently reduced membrane potential (Fig. 7a, traces 1, 3, Fig. 8, trace 2). $\mathrm{Ca}^{2+}$-induced potential dissipation was partially inhibited by $0.001 \mathrm{M}$ EGTA (Figs. 7b, 8b) and $1 \mu \mathrm{M}$ Ru red (Fig. 8a). In the EGTA-free and EGTA-containing media, ferutinin alone dose-dependently $(10-60 \mu \mathrm{M})$ changed the intensity of probe fluorescence in mitochondria energized by malate/glutamate, causing potential dissipation (Fig. 7 a, trace 2, Fig. 8a, trace 4, and Fig. 8b, traces 3 and 4 ) and Ru red, MCU inhibitor, did not influence this effect of ferutinin (Fig. 8b, traces 3 and 

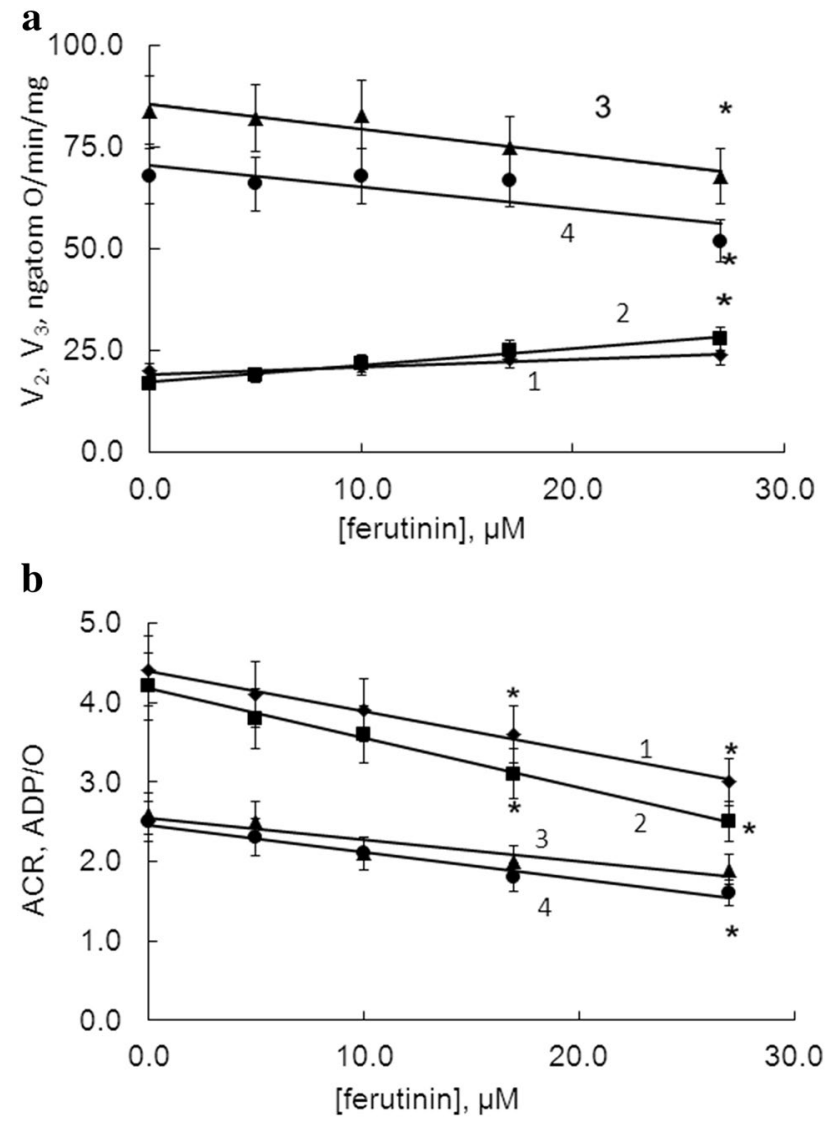

Fig. 6 Effect of ferutinin on respiratory parameters of rat liver mitochondria in the absence $(1,3)$ and in the presence of $20 \mu \mathrm{M} \mathrm{Ca}^{2+}(2$, $4)$. a Substrate-dependent oxygen consumption rate, State $2(1,2)$ and ADP-stimulated oxygen consumption rate, State $3(3,4)$; b acceptor control ratio (ACR) $(1,2)$ and phosphorylation coefficient ADP/O (3, 4). Mitochondria $(0.5 \mathrm{mg}$ of protein $/ \mathrm{ml})$ were introduced into EGTAfree medium: $0.125 \mathrm{M} \mathrm{KCl}, 0.05 \mathrm{M}$ sucrose, $0.01 \mathrm{M}$ Tris- $\mathrm{HCl}$, $0.0025 \mathrm{M} \mathrm{KH}_{2} \mathrm{PO}_{4}, 0.005 \mathrm{M} \mathrm{MgSO}_{4}, \mathrm{pH} 7.4,5 \mathrm{mM}$ glutamate and $1 \mathrm{mM}$ malate, at $25^{\circ} \mathrm{C}$

5). At high ferutinin concentrations $(60 \mu \mathrm{M})$, we observed a rapid loss of membrane potential in the absence of $\mathrm{Ca}^{2+}$ (Fig. 8b, trace 4). When mitochondria were exposed to $10 \mu \mathrm{M}$ ferutinin in the presence of exogenous $10 \mu \mathrm{M} \mathrm{Ca}^{2+}$, the terpenoid considerably enhanced the effect of $\mathrm{Ca}^{2+}$ on the membrane potential and completely depolarized the inner mitochondrial membrane (Fig. 7a, trace 3). Since ferutinin influenced the mitochondrial membrane potential in the presence of EGTA, we suggested the possibility of other ions transportation (not only $\mathrm{Ca}^{2+}$ ) by ferutinin. Ru red $(10 \mu \mathrm{M})$ completely inhibited the $\mathrm{Ca}^{2+}$-induced decrease of the mitochondrial membrane potential (Fig. 7a, curve 3). In the presence of varying concentrations of ferutinin $(10-20 \mu \mathrm{M})$, the $\mathrm{Ca}^{2+}$ injection in mitochondrial suspension resulted in effective mitochondrial potential dissipation despite the MCU inhibition by Ru red (Fig. 8a, traces 5 and 6 ), and this effect enhanced as the ferutinin concentration increased.
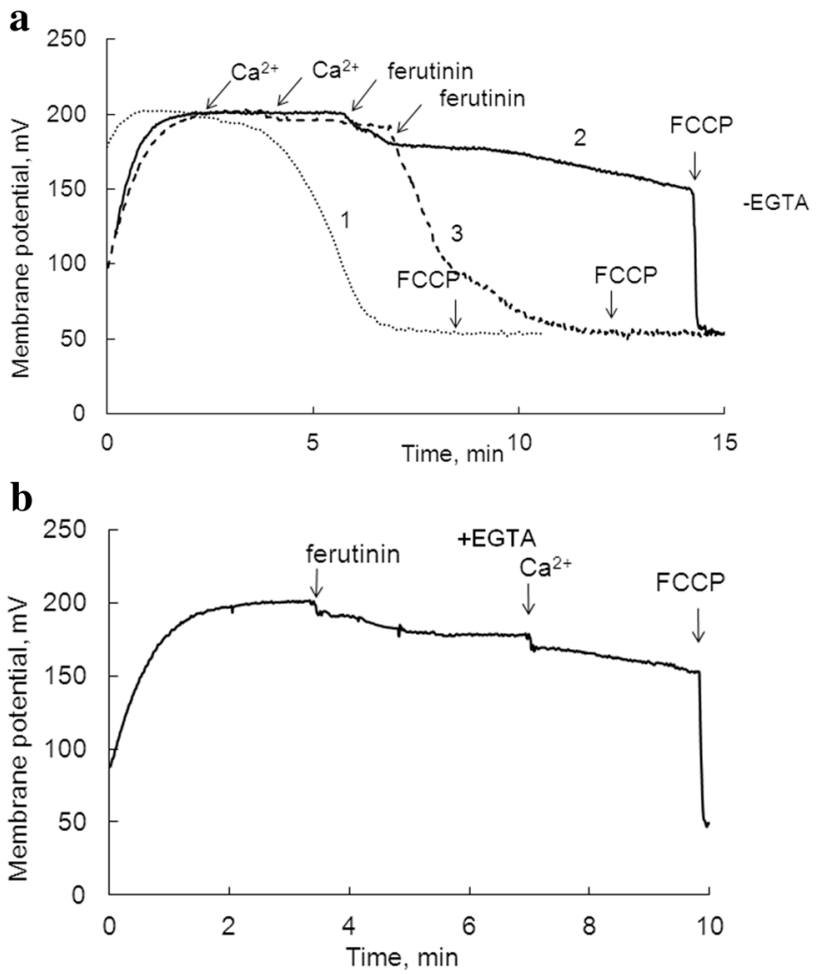

Fig. 7 Representative traces of time-dependences of ferutinin- and $\mathrm{Ca}^{2+}$-induced dissipation of mitochondrial membrane potential. a Effects of $30 \mu \mathrm{M} \mathrm{Ca}^{2+}(1) ; 10 \mu \mathrm{M}$ ferutinin (2); $10 \mu \mathrm{M} \mathrm{Ca}^{2+}+10 \mu \mathrm{M}$ ferutinin (3) in EGTA-free medium; $\mathbf{b}$ effects of $10 \mu \mathrm{M}$ ferutinin and $10 \mu \mathrm{M} \mathrm{Ca}^{2+}$ in EGTA-containing medium. The arrows indicate additions of $10 \mu \mathrm{M}$ ferutinin (ferutinin), $10 \mu \mathrm{M} \mathrm{Ca}^{2+}\left(\mathrm{Ca}^{2+}\right)$ and $0.5 \mu \mathrm{M}$ FCCP (FCCP) to mitochondria suspension $(0.3 \mathrm{mg}$ of protein $/ \mathrm{ml})$ in the medium: $0.05 \mathrm{M}$ sucrose, $0.125 \mathrm{M} \mathrm{KCl}, 0.01 \mathrm{M}$ Tris- $\mathrm{HCl}$, $0.0025 \mathrm{M} \mathrm{KH}_{2} \mathrm{PO}_{4}, 0.005 \mathrm{M} \mathrm{MgSO}_{4}$, and $0.001 \mathrm{M}$ EGTA (or without EGTA), $\mathrm{pH} 7.4$, at $25^{\circ} \mathrm{C}$. The mitochondrial membrane potential was detected using the fluorescent dye safranin $\mathrm{O}(8 \mu \mathrm{M})$ at $\lambda_{\mathrm{ex}} / \lambda_{\mathrm{em}}$ $495 / 586 \mathrm{~nm}$ at $25{ }^{\circ} \mathrm{C}$ and $5 \mathrm{mM}$ glutamate and $1 \mathrm{mM}$ malate as substrates

\section{Discussion}

Mitochondria, in addition to compartmentalization of the major metabolic pathways (e.g., ATP synthesis by OXPHOS), regulating cellular redox state and thermogenesis and producing most of cellular ROS, are highly involved in cellular calcium homeostasis through MCU. In the present work, we evaluated the effect of ferutinin on membrane $\mathrm{Ca}^{2+}$ permeability using isolated rat liver mitochondria. Earlier Abramov and Duchen (2003) suggested that ferutinin acted on the mitochondrial membrane as an electrogenic selective $\mathrm{Ca}^{2+}$ uniporter and may provide a valuable tool to promote both mitochondrial $\mathrm{Ca}^{2+}$ overload and $\mathrm{Ca}^{2+}$-dependent opening of MPT pores in many cell types.

In our experiments, $\mathrm{Ca}^{2+}$ induced considerable inhibition of mitochondrial respiration and uncoupling of oxygen consumption and phosphorylation processes as well as 

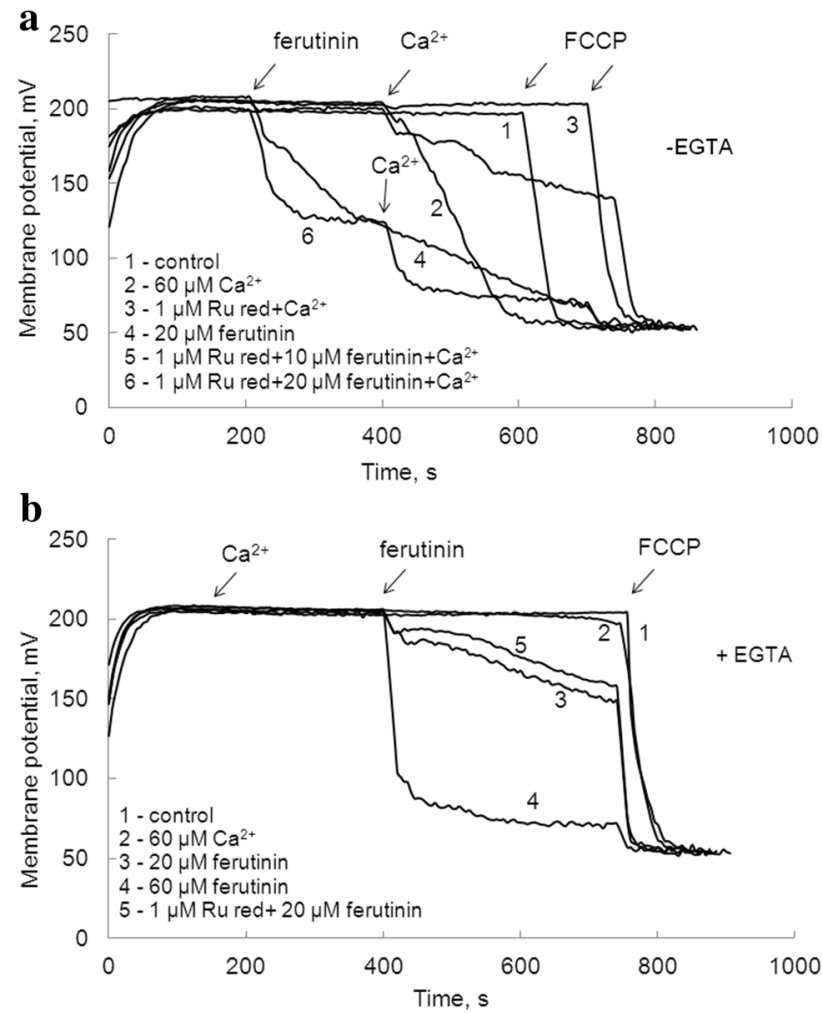

Fig. 8 Representative traces of time-dependences of ferutinin- and $\mathrm{Ca}^{2+}$-induced dissipation of mitochondrial membrane potential. a Control, mitochondria in the absence of $\mathrm{Ca}^{2+}$-ions (1); effects of $60 \mu \mathrm{M} \mathrm{Ca}{ }^{2+}(2) ; 10 \mu \mathrm{M}$ Ru red $+60 \mu \mathrm{M} \mathrm{Ca}^{2+}$ (3); $20 \mu \mathrm{M}$ ferutinin (4); $1 \mu \mathrm{M} \mathrm{Ru}$ red $+10 \mu \mathrm{M}$ ferutinin $+60 \mu \mathrm{M} \mathrm{Ca}^{2+}(5) ; 1 \mu \mathrm{M}$ $\mathrm{Ru}$ red $+20 \mu \mathrm{M}$ ferutinin $+60 \mu \mathrm{M} \mathrm{Ca}{ }^{2+}(6)$ in EGTA-free medium; b control, mitochondria in the absence of $\mathrm{Ca}^{2+}$-ions (1); effects of $60 \mu \mathrm{M} \mathrm{Ca}^{2+}$ (2); $20 \mu \mathrm{M}$ ferutinin (3); $60 \mu \mathrm{M}$ ferutinin (4); $1 \mu \mathrm{M} \mathrm{Ru}$ red $+20 \mu \mathrm{M}$ ferutinin (5) in EGTA-containing medium. The arrows indicate additions of ferutinin (ferutinin), $60 \mu \mathrm{M} \mathrm{Ca}^{2+}\left(\mathrm{Ca}^{2+}\right)$, and $0.5 \mu \mathrm{M}$ FCCP (FCCP) to mitochondria suspension ( $0.3 \mathrm{mg}$ of protein/ $\mathrm{ml}$ ) in the medium: $0.05 \mathrm{M}$ sucrose, $0.125 \mathrm{M} \mathrm{KCl}, 0.01 \mathrm{M}$ Tris- $\mathrm{HCl}$, $0.0025 \mathrm{M} \mathrm{KH}_{2} \mathrm{PO}_{4}, 0.005 \mathrm{M} \mathrm{MgSO}_{4}$, and 0.001 M EGTA (or without EGTA), pH 7.4, at $25^{\circ} \mathrm{C}$. The mitochondrial membrane potential was detected using the fluorescent dye safranin $\mathrm{O}(8 \mu \mathrm{M})$ at $\lambda_{\mathrm{ex}} / \lambda_{\mathrm{em}}$ $495 / 586 \mathrm{~nm}$ at $25^{\circ} \mathrm{C}$ and $5 \mathrm{mM}$ glutamate and $1 \mathrm{mM}$ malate as substrates

resulted in MPT pore formations and potential dissipation in EGTA-free medium. These effects are mediated by MCU because the direct uniporter inhibition by Ru red completely prevented $\mathrm{Ca}^{2+}$-induced mitochondria swelling and membrane potential loss (Figs. 4, 8). Interestingly, earlier works of the Bernardi group (Petronilli et al. 1993a) showed that $\mathrm{Ru}$ red induced osmotic swelling of mitochondria, de-energized by antimycin and FCCP. The authors suggested that $\mathrm{Ru}$ red decreased the reversal $\mathrm{Ca}^{2+}$ efflux (Petronilli et al. 1993a). It was demonstrated that $\mathrm{Ca}^{2+}$ at concentrations of $100-1000 \mathrm{nmol} / \mathrm{mg}$ of protein dose- and time-dependently inhibited mitochondrial respiration, did not influence the activities of NADH- and pyruvate dehydrogenases and decreased the production of ROS/RNS in mitochondria (Pandya et al. 2013). We observed that ferutinin alone influenced mitochondrial respiration and declined mitochondrial membrane potential in both the EGTA-free and EGT-containing media and induced MPT at higher concentrations in the EGTA-free medium. It was shown previously that ferutinin-induced energy-independent swelling of mitochondria in isosmotic nitrate solution with the following selectivity to ions $\mathrm{Ca}^{2+}>\mathrm{Mg}^{2+}>\mathrm{Na}^{+}>\mathrm{K}^{+}>\mathrm{Ba}^{2+}>\mathrm{Sr}^{2+}$ (Abramov et al. 2001). $\mathrm{Tl}^{+}$-induced MPT pore opening as well as subsequent increase in swelling of $\mathrm{Ca}^{2+}$-loaded rat liver mitochondria, drop of mitochondrial membrane potential, and decrease in mitochondrial respiration were observed earlier (Korotkov and Saris 2011; Korotkov et al. 2016). These effects of $\mathrm{Tl}^{+}$ increased in nitrate media containing monovalent cations (Korotkov and Saris 2011).

For evaluation of the role of MCU in the effects of ferutinin on the mitochondrial calcium uptake and differentiation of it from the possible direct ferutinin action on the inner mitochondrial membrane, we used Ru red, a specific MCU inhibitor. In our experiments, Ru red did not influence the effect of ferutinin on $\mathrm{Ca}^{2+}$-induced MPT and the mitochondrial membrane depolarization (Figs. 4, 8). One can suggest that ferutinin acts as $\mathrm{Ca}^{2+}$-ionophore that directly increases the inner mitochondrial membrane permeability to $\mathrm{Ca}^{2+}$-ions, which was earlier shown for planar lipid bilayer membranes and liposomes (Zamaraeva et al. 1997; Abramov et al. 2001; Dubis et al. 2015).

It is known that entrance of positive $\mathrm{Ca}^{2+}$-ions to mitochondria results in a decrease in the mitochondrial membrane potential, which prevents a flow of the succeeding ion portions. The stimulation of $\mathrm{Ca}^{2+}$-induced MPT pore formations by ferutinin was higher in the case of respiring mitochondria, possibly due to membrane potential restoring by the electron transport chain. Ferutinin considerably enhanced the $\mathrm{Ca}^{2+}$ effect on membrane permeabilization (MPT pore formations) and potential dissipation and did not significantly influence the $\mathrm{Ca}^{2+}$ effect on mitochondrial respiration.

The ferutinin-induced mitochondrial cell depolarization was not shown to be affected by inhibition of $\mathrm{Ca}^{2+} / 2 \mathrm{Na}^{+}$-exchanger, but was completely blocked by CsA, suggesting that the MPT pore opening appeared to be the major mechanism of ferutinin-induced mitochondrial depolarization rather than any direct action of the ionophore on the mitochondrial membrane (Abramov and Duchen 2003). On the other hand it is well known that $\mathrm{Ca}^{2+}$ ion accumulation in mitochondria in a dose-dependent manner led to mitochondrial membrane depolarization, and it was suggested that this depolarization preceded MPT (Golovach et al. 2017). However, ferutinin-induced mitochondrial depolarization as well as respiration uncoupling could be also provoked by driving monovalent cations in the absence 
of $\mathrm{Ca}^{2+}$ (Abramov et al. 2001). It was demonstrated earlier that in the absence of external $\mathrm{Ca}^{2+}$ and in the presence of $\mathrm{Ca}^{2+}$-chelator (BAPTA-2AM), ferutinin also induced depolarization of mitochondria, although to a lesser extent (Abramov and Duchen 2003). This indicated some additional effects of ferutinin on mitochondria which were not connected with its $\mathrm{Ca}^{2+}$-mobilizing effects. This is possibly associated with ferutinin influence on the estrogenic receptor of mitochondria; its occurrence has been demonstrated recently (Yang et al. 2004) or on activation of signaling pathways. Ferutinin was previously demonstrated to increase brain nitric oxide synthase activity (Colman-Saizarbitoria et al. 2006) and adenylate cyclase activity in the heart membranes of rats (our unpublished data).

In our experiments, CsA did not completely inhibit $\mathrm{Ca}^{2+}$-ferutinin-induced MPT pore formation. We suggested that other, CsA-nonsensitive, mechanisms could be involved in ferutinin-induced $\mathrm{Ca}^{2+}$-dependent mitochondrial swelling. At the same time, it has been concluded recently that $\mathrm{Ca}^{2+}$-sensitive channel activity displayed multiple conductances ranging from 10 to $1000 \mathrm{pS}$, as recorded by patchclamping mitochondrial inner membrane or mitoplast preparations (Jonas et al. 2015). One type, with conductance of up to $1.3 \mathrm{nS}$, was CsA inhibitable, but the other type, with smaller conductance (107 pS), was resistant to CsA (Jonas et al. 2015).

Earlier data demonstrated that in many cells, mitochondrial $\mathrm{Ca}^{2+}$ loading by ferutinin provoked CsA-sensitive MPT pore opening (Abramov and Duchen 2003). Our present findings using isolated rat liver mitochondria indicate that ferutinin, facilitating $\mathrm{Ca}^{2+}$ penetration through the inner mitochondrial membrane, enhanced $\mathrm{Ca}^{2+}$ effects on mitochondrial membrane potential and MPT pore formation rather than on mitochondrial respiration. In this way, ferutinin can promote $\mathrm{Ca}^{2+}$-dependent apoptotic cell death. However, other mechanisms, such as driving of monovalent cations or receptor-dependent activation of signaling pathways, may be involved in the mitochondrial effects of ferutinin.

\section{Compliance with Ethical Standards}

Conflict of interest The authors declare that they have no conflict of interest.

Informed Consent The informed consent was obtained from all the individual participants involved in the study.

\section{References}

Abramov AY, Duchen MR (2003) Action of ionomycin, 4-BrA23187 and novel electrogenic $\mathrm{Ca}^{2+}$ ionophore on mitochondria in intact cells. Cell Calcium 33:101-112
Abramov AY, Zamaraeva MV, Hagelgans AI, Azimov RR, Krasilnikov OV (2001) Influence of plant terpenoids on the permeability of mitochondria and lipid bilayers. Biochim Biophys Acta 1512(1):98-110

Akerman KEO, Wikström MKF (1976) Safranine as a probe of the mitochondrial membrane potential. FEBS Lett 6:191-197

Amin A, Gali-Muhtasib H, Osker M, Schneider-Stock R (2009) Overview of major classes of plant-derived anticancer drugs. Int $\mathbf{J}$ Biomed Sci 5(1):1-11

Arghiani N, Matin MM, Bahrami AR, Iranshashi M, Sazgarnia A, Rassouli FB (2014) Investigating anticancer properties of the sesquiterpene ferutinin on colon carcinoma cells, in vitro and in vivo. Life Sci 109:87-94

Azzolin L, Stockum S, Basso E, Petronilli V, Forte M, Bernardi P (2010) The mitochondrial permeability transition from yeast to mammals. FEBS Lett 584:2504-2509

Baranov SV, Stavrovskaya IG, Brown AM, Tyryshkin AM, Kristal BS (2008) Kinetic model for $\mathrm{Ca}^{2+}$-induced permeability transition in energized liver mitochondria discriminates between inhibitor mechanisms. J Biol Chem 283:665-676

Baughman JM, Perocchi F, Girgis HS, Plovanich M, Belcher-Timme CA, Sancak Y, Bao XR, Strittmatter L, Goldberger O, Bogorad RL, Koteliansky V, Mootha VK (2011) Integrative genomics identifies MCU as an essential component of the mitochondrial calcium uniporter. Nature 476:341-345

Costantini P, Jacotot E, Decaudin D, Kroemer G (2000) Mitochondrion as a novel target of cancer chemotherapy. J Natl Cancer Inst 92(13):1042-1053

Colman-Saizarbitoria T, Boutros P, Amesty A, Bahsas A, Mathison Y, Garrido Mdel R, Israel A (2006) Ferutinin stimulates nitric oxide synthase activity in median eminence of the rat. J Ethnopharmacol 106:327-332

Dalla Via L, Garcia-Argaez AN, Martinez-Vazquez M, Grancara S, Martinis P, Toninello A (2014) Mitochondrial permeability transition as target of anticancer drugs. Curr Pharm Des 20:223-244

Dall' Acqua S, Linardi MA, Maggi F, Nicoletti M, Petitto V, Innocenti G, Basso G, Viola G (2011) Natural daucane sesquiterpenes with antiproliferative activity against human tumor cells. Bioorg Med Chem 19:5876-5885

De Stefani D, Raffaello A, Teardo E, Szabò I, Rizzuto R (2011) A forty-kilodalton protein of the inner membrane is the mitochondrial calcium uniporter. Nature 476:336-340

Dremza IK, Lapshina EA, Kujawa J, Zavodnik IB (2006) Oxygenrelated processes in red blood cells exposed to tert-butyl hydroperoxide. Redox Rep 11:185-192

Dubis A, Zamaraeva MV, Siergiejczyk L, Charishnikova O, Shlyonsky V (2015) Ferutinin as a $\mathrm{Ca}(2+)$ complexone: lipid bilayers, conductometry, FT-IR, NMR studies and DFT-B3LYP calculations. Dalton Trans 44(37):16506-16515

Duchen MR (2004) Mitochondria in health and disease: perspectives on a new mitochondrial biology. Mol Aspects Med 25(4):365-451

Ferretti M, Bertoni L, Cavani F, Benincasa M, Sena P, Carnevale G, Zavatti M, Viesti VD, Zanoli P, Palumbo C (2012) Structural and histomorphometric evaluations of ferutinin effects on the uterus of ovariectomized rats during osteoporosis treatment. Life Sci 90(3-4):161-168

Ferretti M, Cavani F, Manni P, Carnevale G, Bertoni L, Zavatti M, Palumbo C (2014) Ferutinin dose-dependent effects on uterus and mammary gland in ovariectomized rats. Histol Histopathol 29(8):1027-1037

Fulda S (2010) Modulation of apoptosis by natural products for cancer therapy. Planta Med 76(11):1075-1079

Gao M, Wong SY, Lau PM, Kong SK (2013) Ferutinin induces in vitro eryptosis/erythroptosis in human erythrocytes through membrane permeabilization and calcium influx. Chem Res Toxicol 26(8):1218-1228 
Geroushi A, Auzi AA, Elhwuegi AS, Elzawam F, Berretu A, Hanar L, Sarker SD (2011) Antiinflammatory sesquiterpenes from the root oil of Ferula hermonis. Phytother Res 25:774-777

Golovach NG, Cheshchevik VT, Lapshina EA, Ilyich TB, Zavodnik IB (2017) Calcium-induced mitochondrial permeability transitions: parameters of $\mathrm{Ca}^{2+}$ ion interactions with mitochondria and effects of oxidative agents. J Memb Biol 250:225-236

Gorlach S, Fichna J, Lewandowska U (2015) Polyphenols as mitochondria-targeted anticancer drugs. Cancer Lett 366:141-149

Hoffman NE, Chandramoorthy HC, Shanmughapriya S, Zhang XQ, Vallem S, Doonan PJ, Malliankaraman K, Guo S, Rajan S, Elrod JW, Koch WJ, Cheung JY, Madesh M (2014) SLC25A23 augments mitochondrial $\mathrm{Ca}^{2+}$ uptake, interacts with $\mathrm{MCU}$, and induces oxidative stress-mediated cell death. Mol Biol Cell 25:936-947

Ignatkov V, Akhmedkhodzhaeva KS, Babichev VN (1990) The effect of tefesterol on the secretion of luteinizing hormone from the hypophysis. Farmakol Toksikol 53:37-38

Ikeda K, Arao Y, Otsuka H, Nomoto S, Horiguchi H, Kato S, Kayama F (2002) Terpenoids found in the umbelliferae family act as agonists/antagonists for ER(alpha) and ERbeta: differential transcription activity between ferutinine-liganded ER(alpha) and ERbeta. Biochem Biophys Res Commun 291:354-360

Johnson D, Lardy HA (1967) Isolation of liver or kidney mitochondria. Methods Enzymol 10:94-101

Jonas EA, Porter CA Jr, Beutner G, Mnatsakanyan N, Alavian K (2015) Cell death disguised: the mitochondrial permeability transition pore as the c-subunit of the F1FO ATP synthase. Pharmacol Res 99:382-392

Kirichok Y, Krapivinsky G, Clapham DE (2004) The mitochondrial calcium uniporter is a highly selective ion channel. Nature 427:360-364

Korotkov SM, Konovalova SA, Brailovskaya IV, Saris NE (2016) To involvement the conformation of the adenine nucleotide translocase in opening the $\mathrm{Tl}(+)$-induced permeability transition pore in $\mathrm{Ca}(2+)$-loaded rat liver mitochondria. Toxicol In Vitro 32:320 332. https://doi.org/10.1016/j.tiv.2016.01.015

Korotkov SM, Saris NE (2011) Influence of $\mathrm{Tl}(+)$ on mitochondrial permeability transition pore in $\mathrm{Ca}(2+)$-loaded rat liver mitochondria. J Bioenerg Biomembr 43(2):149-162. https://doi. org/10.1007/s10863-011-9341-z

Kowaltowski AJ (2000) Alternative mitochondrial functions in cell physiopathology: beyond ATP production. Braz J Med Biol Res 33(2):241-250

Lhuillier A, Fabre N, Cheble E, Oueida F, Maurel S, Valentin A, Fouraste I, Moulis C (2005) Daucane sesquiterpenes from Ferula hermonis. J Nat Prod 68:468-471

Lowry OH, Rosebrough NJ, Farr AL, Randall RJ (1951) Protein measurement with the Folin phenol reagent. J Biol Chem 193:265-275

Macho A, Blanco-Molina M, Spagliardi P, Appendino G, Bremner P, Heinrich M, Fiebich BL, Muñoz E (2004) Calcium ionophoretic and apoptotic effects of ferutinin in the human Jurkat T-cell line. Biochem Pharmacol 68(5):875-883

Matin MM, Nakhaeizadeh H, Bahrami AR, Iranshahi M, Arghiani N, Rassouli FB (2014) Ferutinin, an apoptosis inducing terpenoid from Ferula ovina. Asian Pac J Cancer Prev 15:2123-2128

Modzelewska A, Sur S, Kumar SK, Khan SR (2005) Sesquiterpenes: natural products that decrease cancer growth. Curr Med Chem Anticancer Agents 5(5):477-499

Mondal S, Bandyopadhyay S, Ghosh MK, Mukhoppadhyay S, Roy S, Mandal C (2012) Natural products: promising resources for cancer drug discovery. Anticancer Agents Med Chem 12(1):49-75
Moore AL, Bonner WD (1982) Measurements of membrane potentials in plant mitochondria with the safranine method. Plant Physiol 70:1271-1276

Ouyang L, Luo Y, Tian M, Zhang SY, Lu R, Wang JH, Kasimu R, Li $X$ (2014) Plant natural products: from traditional compounds to new emerging drugs in cancer therapy. Cell Prolif 47(6):506-515

Pandya JD, Nukala VN, Sullivan PG (2013) Concentration dependent effect of calcium on brain mitochondrial bioenergetics and oxidative stress parameters. Front Neuroenergetics 5:10. https://doi. org/10.3389/fnene. 2013.00010

Petronilli V, Cola C, Bernardi P (1993a) Modulation of the mitochondrial cyclosporin A-sensitive permeability transition pore. II. The minimal requirements for pore induction underscore a key role for transmembrane electrical potential, matrix $\mathrm{pH}$, and matrix $\mathrm{Ca}^{2+}$. J Biol Chem 268:1011-1016

Petronilli V, Cola C, Massari S, Colonna R, Bernardi P (1993b) Physiological effectors modify voltage sensing by the cyclosporine A-sensitive permeability transition pore of mitochondria. J Biol Chem 268:21939-21945

Poli F, Appendino G, Sacchetti G, Ballero M, Maggiano N, Ranelletti DO (2005) Antiproliferative effects of daucane esters from Ferula communis and F. arrigonii on human colon cancer cell lines. Phytother Res 19:152-157

Safi R, Rodriguez F, Hilal G, Diab-Assaf M, Diab Y, El-Sabban M, Najjar F, Delfourne E (2016) Hemisynthesis, antitumoral effect, and molecular docking studies of ferutinin and its analogues. Chem Biol Drug Des 87(3):382-397

Saidkhodzjaev AJ, Nikonov GK (1973) The constituents of ferutinin. Chem Nat Prod 1:28-30

Suta S, Maggi F, Nicoletti M, Baldan V, Dall Acqua S (2017) New drugs from old natural compounds: scarcely investigated sesquiterpenes as new possible therapeutic agents. Curr Med Chem. https ://doi.org/10.2174/0929867324666170404150351

Szewczyk A, Wojtczak L (2002) Mitochondria as a pharmacological target. Pharmacol Rev 54:101-127

Yang SH, Liu R, Perez EJ, Wen Y, Stevens SM, Valencia T, BrunZinkernagel AM, Prokai L, Will Y, Dykens J, Koulen P, Simpkins W (2004) Mitochondrial localization of estrogen receptor $\beta$. Proc Natl Acad Sci USA 101(12):4130-4135

Zamaraeva MV, Hagelgans AI, Abramov AY, Ternovsky VI, Merzlyak PG, Tashmukhamedov BA, Saidkhodzjaev AI (1997) Ionophoretic properties of ferutinin. Cell Calcium 22(4):235-241

Zamaraeva MV, Hagelgans AI, Lubnina AI, Abramov AY, Ahmedhodjaeva HS, Saidhodjaev AI, Glazyrina NG (1999) Hormonal activity and membrane action of plants terpenoids. Cell Mol Biol Lett 4(2): 189

Zamaraeva M, Charishnikova O, Saidkhodjaev A, Isidorov V, Granosik M, Rozalski M, Watala C (2010) Calcium mobilization by the plant estrogen ferutinin does not induce blood platelet aggregation. Pharmcol Rep 62:1117-1126

Zavatti M, Bertoni L, Maraldi T, Resca E, Berreti F, Guida M, La Sala GB, De Pol A (2015) Critical-size bone defect repair using amniotic fluid stem cell/collagen constructs: effect of oral ferutinin treatment in rats. Life Sci 121:174-183

Zavodnik IB, Dremza IK, Cheshchevik VT, Lapshina EA, Zamaraewa M (2013) Oxidative damage of rat liver mitochondria during exposure to t-butyl hydroperoxide. Role of $\mathrm{Ca}^{2+}$ ions in oxidative processes. Life Sci 92(23):1110-1117 